\title{
Modafinil disrupts prepulse inhibition in mice: strain differences and involvement of dopaminergic and serotonergic activation.
}

Perrin $\underline{\text { Kwek }}^{1}$ and Maarten van den Buuse ${ }^{1,2}$

(1) Behavioural Neuroscience Laboratory, Mental Health Research Institute, Parkville, Melbourne, Australia; (2) Department of Pharmacology, University of Melbourne, Australia.

Correspondence and proofs:

Assoc. Prof. Maarten van den Buuse

Behavioural Neuroscience Laboratory

Mental Health Research Institute

University of Melbourne, Kenneth Myer Building

Melbourne, Victoria 3010

Australia

Tel. +61390356624

Fax +61393875061

E-mail mvdbuuse@unimelb.edu.au

\section{ABSTRACT}

Modafinil is a wakefulness-promoting agent with possible beneficial effects for the management of addiction and in psychiatric conditions, but also with abuse potential of its own. The mechanism of action of modafinil remains unclear. We studied pharmacological 
mechanisms in the effect of modafinil on prepulse inhibition (PPI), a model of sensorimotor gating. Mice were tested in automated startle boxes after administration of modafinil and antagonist drugs. Oral administration of $100 \mathrm{mg} / \mathrm{kg}$ of modafinil, but not lower doses, caused a significant reduction of PPI in C57B1/6 mice, but not Balb/c mice. This effect of modafinil could be blocked by co-treatment with the dopamine $\mathrm{D}_{2}$ receptor antagonist, haloperidol, and the serotonin $(5-\mathrm{HT}) 2 \mathrm{~A}$ receptor antagonist, ketanserin, but not the $5-\mathrm{HT}_{1 \mathrm{~A}}$ receptor antagonist, WAY100,635. At $30 \mathrm{mg} / \mathrm{kg}$, which did not influence PPI, modafinil inhibited PPI disruption caused by the dopamine transporter inhibitor, GBR12909. There was no interaction between modafinil and the serotonin transporter inhibitor, fluoxetine. There were no consistent effects of modafinil on startle amplitude. These results show that oral modafinil treatment may cause disruption of PPI in mice. This effect was strain-dependent, involving dopamine $\mathrm{D}_{2}$ and $5-\mathrm{HT}_{2 \mathrm{~A}}$ receptor activation, and was likely mediated by an interaction with the dopamine transporter. These results extend our insight into the behavioral effects of modafinil and could be of importance for the clinical use of this agent as they may indicate an increased risk of side-effects in conditions where PPI is already reduced, such as in schizophrenia and bipolar disorder.

Keywords: modafinil, dopamine, serotonin, prepulse inhibition, startle, schizophrenia

\section{INTRODUCTION}

Modafinil is an anti-narcolepsy drug widely used off-label and as a mild stimulant (Kumar, 2008; Minzenberg and Carter, 2008). Modafinil has been trialed in the management of drug abuse and dependence (Martinez-Raga et al., 2008; Heinzerling et al., 2010) and its cognitive and stimulant effects could be useful in the treatment of schizophrenia and bipolar disorder 
(Morein-Zamir et al., 2007). In addition, modafinil is becoming widely used in social settings, as a doping agent and to combat jet-lag (Kumar, 2008; Minzenberg and Carter, 2008).

The pharmacological mechanism of action of modafinil may be by interacting with the dopamine transporter increasing dopamine release in the basal forebrain (Volkow et al., 2009; Zolkowska et al., 2009; Young and Geyer, 2010) resulting in stimulation of dopamine $\mathrm{D}_{1}$ and $\mathrm{D}_{2}$ receptors (Qu et al., 2008). Thus, modafinil may have effects similar to drugs of abuse such as cocaine and amphetamines (Volkow et al., 2009). In addition to dopaminergic effects, modafinil also increases serotonin release in the cortex (de Saint Hilaire et al., 2001), increases histamine release in the brain which interacts with its behavioural effects (Ishizuka et al., 2008) and may have antidepressant effects (de Saint Hilaire et al., 2001; Ferraro et al., 2005; Regenthal et al., 2009). Therefore the exact pharmacological action of modafinil on behavior remains unclear.

Prepulse inhibition (PPI) is a widely used model of sensorimotor gating, which is the ability to filter extraneous information and focus on relevant input (Swerdlow et al., 2008). Prepulse inhibition is disrupted in schizophrenia and other psychiatric illnesses (Swerdlow et al., 2008) and after treatment with dopamine receptor agonists, dopamine releasing agents and several serotonergic drugs (Geyer et al., 2001). Assessing the effect of modafinil on PPI may therefore inform on its mechanism of action and potential positive and side-effects in schizophrenia. However, in healthy humans and in rats, modafinil had no effect on baseline PPI (Samuels et al., 2007; Regenthal et al., 2009; McFadden et al., 2010). In contrast, after tail pinch stress or REM sleep deprivation in rats, modafinil caused disruption of PPI (Liu et al., 2011) and subchronic modafinil reversed restraint stress-induced deficits in PPI, as well as depression-like behaviours in rats (Regenthal et al., 2009). 
The effects of modafinil on PPI have not been investigated in mice, even though this is the most widely used experimental species in psychiatric and psychopharmacological neuroscience because of the wide availability of genetic modifications. Therefore, and to further elucidate the neuropsychopharmacological mechanism of action of modafinil, we examined its effects on PPI and startle in mice. We administered modafinil orally, similarly to its common use in humans, and used two mouse strains, the $\mathrm{C} 57 \mathrm{Bl} / 6$ and the Balb/c which differ in the regulation of PPI. We used a number of dopamine and serotonin (5-HT) receptor and uptake blockers to delineate the involvement of these neurotransmitter mechanisms in the action of modafinil on PPI.

\section{MATERIALS AND METHODS}

\subsection{Animals}

The study used a total of 67 male C57Bl/6 mice and 56 male Balb/c mice divided into six experiments of 8-12 mice each. Two mouse strains were used because we (Van den Buuse et al., 2007) and others (Paylor and Crawley, 1997) have shown marked strain-related differences in PPI regulation and behavioural effects of modafinil have been shown to differ between mouse strains (Simon et al., 1996). The animals were 8 weeks old at the start of the experiments which took 3-4 weeks to complete for each cohort. The mice were obtained from the Monash University Animal Service, Melbourne, Australia, and were allowed to acclimate in the institute for at least one week before experiments commenced. The animals were kept 4-5 per cage under standard housing conditions with mouse pellet food and tap water available ad libitum. All protocols and procedures were approved by the Animal Experimentation Ethics committee of the Florey Neurosciences Institutes, Melbourne, Australia. 


\subsection{Drugs}

We used Modavigil ${ }^{\circledR}$ tablets (Cephalon Inc./ CSL Biotherapeutics, Australia) each containing $100 \mathrm{mg}$ of modafinil and the following inactive ingredients: lactose, starch-maize, magnesium silicate dihydrate, sodium croscarmellose, povidone, purified talc, and magnesium stearate. The tablets were crushed using a pill crusher and the powder was suspended in a standard suspension vehicle solution (SSV, $0.9 \% \mathrm{w} / \mathrm{v} \mathrm{NaCl}, 0.5 \% \mathrm{w} / \mathrm{v}$ Na-carboxy-methylcellulose, $0.005 \% \mathrm{v} / \mathrm{v}$ benzyl alcohol and $0.004 \% \mathrm{v} / \mathrm{v}$ Tween 80 ). Appropriate doses were diluted in this vehicle and delivered in a $4 \mathrm{ml} / \mathrm{kg}$ body weight final volume using curved $18 \mathrm{G}$ stainless steel gavage needles (Kimani, Kalamunda, Australia). The excipients were diluted with the active ingredients and were not present in the control dose.

The predominantly dopamine $\mathrm{D}_{2}$ receptor antagonist, haloperidol (4-[4-(p-Chlorophenyl)-4hydroxypiperidino]-4'-fluorobutyrophenone, $0.3 \mathrm{mg} / \mathrm{kg}$ (McCaughran et al., 1997; Assié et al., 2006)) was prepared by diluting a commercially available $5 \mathrm{mg} / \mathrm{ml}$ solution (Haldol® ampoules, Searle) with $0.9 \% \mathrm{NaCl}$. The $5-\mathrm{HT}_{2 \mathrm{~A}}$ receptor antagonist, ketanserin (3-(2-[4-(4Fluorobenzoyl)-1-piperidinyl]ethyl)-2,4(1H,3H)-quinazolinedione (+)-tartrate salt, $1 \mathrm{mg} / \mathrm{kg}$ (Gleason and Shannon, 1997; Bradford et al., 2010)), the 5-HT $\mathrm{HA}_{1 \mathrm{~A}}$ receptor antagonist, WAY100,635 (N-[2-[4-(2-Methoxyphenyl)-1-piperazinyl]ethyl]-N-2-pyridinylcyclohexanecarboxamide maleate salt, $1 \mathrm{mg} / \mathrm{kg}$ (Trillat et al., 1998; Krebs-Thomson et al., 2006)), the dopamine transporter inhibitor, GBR12909 (1-(2-[bis(4-Fluorophenyl)methoxy]ethyl)-4-(3phenylpropyl)piperazine dihydrochloride, $5 \mathrm{mg} / \mathrm{kg}$ (Mcgeehan et al., 2004; Young et al., $2010))$ and the serotonin transporter inhibitor, fluoxetine (( \pm$)$-N-Methyl- $\gamma-[4-$ (trifluoromethyl)phenoxy] benzenepropanamine hydrochloride, $10 \mathrm{mg} / \mathrm{kg}$ (Bertrand et al., 2005)) were all purchased from Sigma and dissolved in $0.9 \%$ saline. These drugs were 
injected intraperitoneally (i.p.) at $10 \mathrm{ml} / \mathrm{kg}$. This dosing volume was very well tolerated by the animals.

\subsection{Experimental protocol}

For all experiments, a within-animal repeated-measures protocol was used where every animal received all treatments in that experiment in a pseudo-random sequence. Thus, mice were tested for PPI five times (dose-response studies) or four times (all other studies) with 3-4 days intervals. Two hours before the start of each PPI session, mice were orally injected with modafinil or its vehicle and, where appropriate, immediately after that injected i.p. with saline or the antagonist drug of choice of that experiment. The two-hour interval was based on observations in rats that oral administration of modafinil leads to peak plasma concentrations between 30 and 45 minutes after treatment with the plasma half-life of modafinil in this species being 12.3 hours (Regenthal et al., 2009). After these experiments were completed, a more recent study in mice of the Kunming strain suggested a half-life and duration of action of modafinil of approximately 4 hours (Ma et al., 2012), well in excess of the two-hour interval used here.

In the first experiment, mice were orally treated with SSV solution or 3, 10, 30 or $100 \mathrm{mg} / \mathrm{kg}$ modafinil in SSV. These doses were chosen on the basis of previous studies showing biological effects in mice and rats and information on circulating levels of modafinil after these doses in rats and clinical doses in humans (Rao and Shinde, 2009; Regenthal et al., 2009; Volkow et al., 2009) although it should be noted that similar studies in mice have not been done. Because of the results of this dose-response study, in subsequent antagonist experiments, modafinil was always given at $100 \mathrm{mg} / \mathrm{kg}$. The only exception was the study of modafinil treatment combined with the dopamine transporter ligand, GBR12909. Because 
preliminary studies found that GBR12909 significantly reduced PPI on its own, we chose the lowest effective dose of GBR12909 and reduced the dose of modafinil to $30 \mathrm{mg} / \mathrm{kg}$ to avoid a 'floor effect' on PPI. This experiment was done only in C57Bl/6 mice. In all combination experiments, mice received four treatments: SSV/saline, SSV/antagonist, modafinil/saline and modafinil/antagonist.

PPI was assessed as previously described in detail (Van den Buuse et al., 2007). Briefly, we used an automated SR-LAB startle system (San Diego Instruments). Each unit consisted of a small Plexiglas cylinder on a platform under which a sensitive piezoelectric sensor was mounted. The cylinders were $5 \mathrm{~cm}$ in diameter and could be closed on both ends. During the sessions, the animals remained in the cylinders within a sound-attenuating cabinet where a 70 $\mathrm{dB}$ white background noise was delivered through speakers in the ceiling of the box. For all experiments, we used a PPI session which consisted of 104 trials with a variable intertrial interval of 12-28 s (average $19 \mathrm{~s}$ ). The first three minutes of the session were a $70 \mathrm{~dB}$ background noise presentation, allowing further acclimation to the test environment. The session commenced and finished with eight $115 \mathrm{~dB}, 40 \mathrm{~ms}$ pulse-alone trials. Together with two blocks of eight pulse-alone trials from the main part of the session, these startle blocks were used to calculate average startle amplitude across the session. The main part of the session included eight of each of the following prepulse-pulse trials: PP2P115, PP4P115, PP8P115 and PP16P115 at $30 \mathrm{~ms}$ between the start of the $20 \mathrm{~ms}$ prepulse and start of the pulse, and at $100 \mathrm{~ms}$ between the start of the prepulse and the pulse. PP2, PP4, PP8 and PP16 indicates $2,4,8$ or $16 \mathrm{~dB}$ above the $70 \mathrm{~dB}$ background, i.e. $72,74,78$ and $86 \mathrm{~dB}$ prepulses. We used two inter-stimulus intervals (ISI) because there are several examples in rodents and humans of differential group or drug effects depending on the ISI (e.g. (Swerdlow et al., 2006; Van den Buuse et al., 2007; Vollenweider et al., 2007)). In addition to the pulse-alone and 
prepulse-pulse trials, the session included eight 'NOSTIM' trials, where no startle stimulus was presented, to check for non-specific movement artifacts. Percentage PPI was calculated as $\% \mathrm{PPI}=($ pulse-alone - prepulse-pulse combination $) /$ pulse-alone $\mathrm{x} 100$.

\subsection{Statistical analysis}

All data were expressed as mean \pm standard error of the mean (S.E.M.). Analysis of variance (ANOVA) with repeated measures was used to assess main treatment effects on startle and PPI. Because analysis of prepulse intensity always resulted in highly significant $\mathrm{P}$ values but few interactions with other factors, PPI data in this paper are presented as the average of the four prepulse levels at each ISI. Full details on individual prepulse intensities are shown in Supplementary Tables. Similarly, startle amplitude consistently habituated over the course of the PPI session but there were few interactions of startle pulse block with any of the treatments. Therefore, to simplify data presentation, startle amplitudes are presented here as the average of the 40 pulse-alone trials over the entire PPI session. In the ANOVAs, the between-group factor was Strain (Balb/c vs. $\mathrm{C} 57 \mathrm{Bl} / 6)$ and the within-animal repeated measures factors were modafinil dose (mod, 5 levels) in the dose-response study or modafinil (mod, 2 levels) and antagonist (haloperidol (Hal), ketanserin (Ket), WAY100,635 (WAY), GBR12909 (GBR) or fluoxetine (Flu), two levels each). Where appropriate, further ANOVAs were done in individual strains (see Supplementary Tables) or between pairs of treatments. In all cases, when $\mathrm{P}<0.05$, differences were considered statistically significant.

\section{RESULTS}

\subsection{Modafinil dose-response studies (Fig. 1, Supplementary Table 1)}

Average startle was higher in Balb/c than in $\mathrm{C} 57 \mathrm{Bl} / 6$ mice (main effect of Strain $\mathrm{F}(1,21)=10.1, \mathrm{P}=0.004)$. There was no significant effect of modafinil treatment on startle 
amplitude in Balb/c mice. In C57B1/6 mice, the main effect of modafinil dose was significant $(\mathrm{F}(4,44)=8.7, \mathrm{P}<0.001)$ and further pairwise comparison showed that $100 \mathrm{mg} / \mathrm{kg}$ of modafinil, but not any of the other doses, significantly reduced startle amplitudes compared to the control condition in this strain (Fig. 1).

At the $30 \mathrm{~ms}$ ISI, PPI tended to be higher in Balb/c mice than in C57Bl/6 mice (main effect of Strain $\mathrm{F}(1,22)=5.2, \mathrm{P}=0.033)$. Modafinil treatment reduced PPI in $\mathrm{C} 57 \mathrm{Bl} / 6$ mice, but not Balb/c mice (Dose $\mathrm{x}$ Strain interaction $\mathrm{F}(4,88)=3.1, \mathrm{P}=0.020)$. Further analysis of data from C57Bl/6 mice confirmed the overall effect of modafinil (main effect of Dose $\mathrm{F}(4,44)=4.3$, $\mathrm{P}=0.005)$ which reached significance at the $100 \mathrm{mg} / \mathrm{kg}$ dose $(\mathrm{P}=0.012)$ and was at trend level at the $30 \mathrm{mg} / \mathrm{kg}$ dose $(\mathrm{P}=0.055)$.

Also at the $100 \mathrm{~ms}$ ISI, PPI was higher in Balb/c mice than in C57B1/6 mice (main effect of Strain $\mathrm{F}(1,22)=16.7, \mathrm{P}<0.001)$. Modafinil treatment again reduced PPI in C57B1/6 mice, but not Balb/c mice (Dose $\mathrm{x}$ Strain interaction $\mathrm{F}(4,88)=4.2, \mathrm{P}=0.003$ ). Further analysis of data from $\mathrm{C} 57 \mathrm{Bl} / 6$ mice confirmed the overall effect of modafinil (main effect of Dose $\mathrm{F}(4,44)=4.8, \mathrm{P}=0.0063)$ which reached significance at the $100 \mathrm{mg} / \mathrm{kg}$ dose $(\mathrm{P}=0.006)$ but not at any of the other doses.

\subsection{Haloperidol and modafinil (Fig. 2, Supplementary Table 2)}

In addition to the expected higher startle amplitudes in Balb/c mice compared to C57B1/6 mice $(\mathrm{F}(1,20)=12.0, \mathrm{P}=0.002)$, ANOVA revealed an interaction of haloperidol and modafinil which was independent of the strain $(\mathrm{F}(1,20)=8.1, \mathrm{P}=0.020)$. Further pair-wise analysis only showed lower startle amplitudes after haloperidol treatment compared to the SSV/saline control condition (main effect $\mathrm{P}=0.015$; Hal $\mathrm{x}$ Strain interaction $\mathrm{P}=0.039$ ). Further analysis in 
Balb/c mice revealed that haloperidol treatment significantly reduced startle in this strain $(\mathrm{P}=0.037)$ but not in $\mathrm{C} 57 \mathrm{Bl} / 6$ mice (Fig. 2).

At the $30 \mathrm{~ms}$ ISI, PPI was higher in Balb/c mice than in C57Bl/6 mice (main effect of Strain $\mathrm{F}(1,22)=43.6, \mathrm{P}<0.001)$. While there were no main effects of haloperidol treatment or modafinil treatment, there was a Hal $\mathrm{x}$ Mod interaction $(\mathrm{F}(1,22)=4.4, \mathrm{P}=0.048)$ suggesting differential effects of modafinil depending on the presence of haloperidol. A similar trend was seen when only data from $\mathrm{C} 57 \mathrm{~B} 1 / 6$ mice were analyzed $(\mathrm{F}(1,11)=4.7, \mathrm{P}=0.052)$. In this strain, modafinil treatment tended to cause a decrease of PPI $(\mathrm{P}=0.094)$ which was not seen if the animals had been co-treated with haloperidol (Fig. 2).

At the $100 \mathrm{~ms}$ ISI, in addition to a higher overall PPI in Balb/c mice than in C57B1/6 mice $(\mathrm{F}(1,22)=80.8, \mathrm{P}<0.001)$, effects of haloperidol and modafinil were seen which significantly depended on the strain (Hal x Strain interaction $F(1,22)=6.8, P=0.016$; Mod x Strain interaction $\mathrm{F}(1,22)=5.5, \mathrm{P}=0.028$; Hal $\mathrm{x}$ Mod $\mathrm{x}$ Strain interaction $\mathrm{F}(1,22)=5.3, \mathrm{P}=0.031)$. Analysis of the individual strains showed that there were no effects of haloperidol or modafinil on PPI in Balb/c mice. In contrast, in C57B1/6 mice, modafinil significantly reduced PPI (main effect $\mathrm{F}(1,11)=7.1, \mathrm{P}=0.022$ ) and this effect was modulated by haloperidol co-treatment (Hal x Mod interaction $\mathrm{F}(1,11)=7.3, \mathrm{P}=0.021)$. Pair-wise comparison confirmed significant PPI disruption after modafinil treatment $(\mathrm{P}=0.021)$ but not after haloperidol treatment or haloperidol + modafinil treatment. PPI at the $100 \mathrm{~ms}$ ISI was significantly higher in $\mathrm{C} 57 \mathrm{Bl} / 6$ mice treated with both haloperidol and modafinil compared to those treated with modafinil only ( $\mathrm{P}=0.006$, Fig. 2). 


\subsection{Ketanserin and modafinil (Fig. 3, Supplementary Table 3)}

Startle amplitudes were higher in this cohort of Balb/c mice compared to C57Bl/6 mice $(\mathrm{F}(1,18)=10.6, \mathrm{P}=0.005)$. An interaction of modafinil and strain $(\mathrm{F}(1,18)=14.9, \mathrm{P}=0.001)$ was caused by a small, but significant increase in startle amplitudes in Balb/c mice after modafinil treatment (main effect in this strain $\mathrm{F}(1,9)=9.8, \mathrm{P}=0.012 ; \mathrm{P}=0.048$ for difference between cotreatment with ketanserin and modafinil compared to control values) (Fig. 3).

At the 30 ms ISI, PPI was higher in Balb/c than in C57B1/6 mice (main effect of Strain $\mathrm{F} 1,18)=16.1, \mathrm{P}=0.001)$. Analysis of the combined data set showed that ketanserin treatment increased PPI (main effect $\mathrm{F}(1,18)=18.4, \mathrm{P}<0.001$ ). Modafinil significantly disrupted PPI and this effect was blocked by ketanserin (Ket $\mathrm{x}$ Mod interaction $\mathrm{F}(1,18)=9.8, \mathrm{P}=0.006)$ in C57Bl/6 mice, but not Balb/c mice (Mod x Strain interaction $\mathrm{F}(1,18)=8.8, \mathrm{P}=0.008$; Ket $\mathrm{x}$ Mod x Strain interaction $F(1,18)=7.7, \mathrm{P}=0.012$ ). Further analysis by strain showed that in C57Bl/6 mice, but not Balb/c mice, modafinil significantly disrupted PPI (main effect $\mathrm{F}(1,9)=12.3, \mathrm{P}=0.007)$ and this effect was blocked by ketanserin co-treatment (Ket $\mathrm{x}$ Mod interaction $\mathrm{F}(1,9)=18.0, \mathrm{P}=0.002$ ). In Balb/c mice ketanserin induced a small increase in PPI (main effect: $\mathrm{F}(1,9)=5.4, \mathrm{P}=0.045$ ). Pair-wise comparison confirmed that in $\mathrm{C} 57 \mathrm{~B} 1 / 6$ mice, compared to vehicle treatment, PPI was significantly lower after modafinil treatment $(\mathrm{P}=0.001)$, but not after a combination of ketanserin and modafinil (Fig. 3). PPI at this ISI was significantly higher after treatment with modafinil and ketanserin compared to modafinil only $(\mathrm{P}=0.001)$.

At the $100 \mathrm{~ms}$ ISI, PPI was higher in Balb/c than in C57Bl/6 mice (main effect of Strain $\mathrm{F} 1,18)=39.6, \mathrm{P}<0.001)$. Analysis of the combined data set again showed that ketanserin treatment increased PPI (main effect $\mathrm{F}(1,18)=16.1, \mathrm{P}=0.001$ ) and that modafinil significantly 
disrupted PPI in C57Bl/6 mice, but not Balb/c mice (Mod x Strain interaction $\mathrm{F}(1,18)=8.0$, $\mathrm{P}=0.011$ ). Further analysis by strain showed that in $\mathrm{C} 57 \mathrm{Bl} / 6$ mice, but not Balb/c mice, modafinil significantly disrupted PPI (main effect $\mathrm{F}(1,9)=11.0, \mathrm{P}=0.009$ ). There was also a main effect of ketanserin treatment $(\mathrm{F}(1,9)=14.5, \mathrm{P}=0.004)$ and a trend for an interaction between ketanserin and modafinil $(\mathrm{F}(1,9)=4.8, \mathrm{P}=0.057)$. No such effects were seen in $\mathrm{Balb} / \mathrm{c}$ mice. Pair-wise comparison confirmed that in $\mathrm{C} 57 \mathrm{Bl} / 6$ mice, compared to vehicle treatment, PPI was significantly lower after modafinil treatment $(\mathrm{P}=0.007)$, but not after ketanserin or a combination of ketanserin and modafinil (Fig. 3). PPI at this ISI was significantly higher after treatment with modafinil and ketanserin compared to treatment with modafinil only $(\mathrm{P}=0.010)$

\subsection{WAY100,635 and modafinil (Fig. 4, Supplementary Table 4)}

Analysis of startle amplitudes in this cohort only revealed higher levels in Balb/c mice than in $\mathrm{C} 57 \mathrm{Bl} / 6$ mice (main effect of Strain $\mathrm{F} 1,18)=18.1, \mathrm{P}<0.001)$.

At the 30 ms ISI, PPI was higher in Balb/c than in C57Bl/6 mice (main effect of Strain $\mathrm{F}(1,18)=19.9, \mathrm{P}<0.001)$. Modafinil disrupted PPI in $\mathrm{C} 57 \mathrm{~B} 1 / 6$ mice but not in Balb/c mice $($ Mod x Strain interaction $\mathrm{F}(1,18)=5.5, \mathrm{P}=0.031)$. Further analysis by strain confirmed a significant effect of modafinil in $\mathrm{C} 57 \mathrm{Bl} / 6$ mice $(\mathrm{F}(1,9)=6.3, \mathrm{P}=0.034)$ but not in Balb/c mice. However, pair-wise comparison failed to show significant differences between the individual treatments in this mouse cohort. WAY100,635 had no effect in either strain (Fig. 4).

Also at the $100 \mathrm{~ms}$ ISI, PPI was higher in Balb/c than in C57B1/6 mice (main effect of Strain $\mathrm{F}(1,18)=35.8, \mathrm{P}<0.001)$. Again, modafinil disrupted PPI in $\mathrm{C} 57 \mathrm{Bl} / 6$ mice but not in Balb/c mice $($ main effect of $\operatorname{Mod} F(1,18)=5.6, \mathrm{P}=0.030$; Mod $x$ Strain interaction $\mathrm{F}(1,18)=9.7$, 
$\mathrm{P}=0.006$ ). Further analysis by strain confirmed a significant effect of modafinil in C57B1/6 mice $(\mathrm{F}(1,9)=9.5, \mathrm{P}=0.013)$ but not in Balb/c mice. There was no significant interaction of WAY100,635 and modafinil treatment. Compared to saline/vehicle treatment, pair-wise comparison in $\mathrm{C} 57 \mathrm{Bl} / 6$ mice showed significant PPI disruption after modafinil treatment $(\mathrm{P}=0.003)$ and combined treatment with WAY100,635 and modafinil $(\mathrm{P}=0.013)$. However, there was no difference between PPI after modafinil treatment and after modafinil and WAY100,635 (Fig. 4).

\subsection{GBR12909 and $30 \mathrm{mg} / \mathrm{kg}$ of modafinil in C57Bl/6 mice (Fig. 5, Supplementary Table 5)}

There was no effect of either GBR12909 or modafinil on startle amplitudes. At the $30 \mathrm{~ms}$ ISI, $30 \mathrm{mg} / \mathrm{kg}$ of modafinil had no effect on PPI. Treatment with $5 \mathrm{mg} / \mathrm{kg}$ of GBR12909 significantly disrupted PPI (main effect: $\mathrm{F}(1,14)=14.0, \mathrm{P}=0.002$ ) and there was a significant interaction of modafinil and GBR12909 treatment $(\mathrm{F}(1,14)=6.0, \mathrm{P}=0.028)$. Further pair-wise analysis revealed that, in the absence of modafinil, $5 \mathrm{mg} / \mathrm{kg}$ of GBR12909 significantly disrupted PPI compared to the SSV/saline control condition $(\mathrm{F}(1,14)=14.8, \mathrm{P}=0.002)$. In contrast, after co-treatment with $30 \mathrm{mg} / \mathrm{kg}$ of modafinil, GBR12909 had no effect on PPI compared to the modafinil-only condition (Fig. 5). Moreover, PPI after the GBR12909/modafinil co-treatment was significantly higher than after GBR12909 only $(\mathrm{F}(1,14)=8.5, \mathrm{P}=0.011)$ but not different from the SSV/saline control condition (Fig. 5).

Also at the $100 \mathrm{~ms}$ ISI, there was no main effect of $30 \mathrm{mg} / \mathrm{kg}$ of modafinil, however treatment with GBR12909 significantly disrupted PPI (main effect: $\mathrm{F}(1,14)=5.5, \mathrm{P}=0.034$ ) and there was a significant interaction of modafinil and GBR12909 treatment $(\mathrm{F}(1,14)=5.0, \mathrm{P}=0.042)$. Compared to the vehicle-treated control condition, GBR12909 caused significant disruption of PPI $(\mathrm{F}(1,14)=7.9, \mathrm{P}=0.014)$. However, after co-treatment with $30 \mathrm{mg} / \mathrm{kg}$ of modafinil and 
GBR12909, PPI was not different compared to the modafinil-only condition (Fig. 5). Similar to the $30 \mathrm{~ms}$ ISI, PPI at the $100 \mathrm{~ms}$ ISI after the GBR12909/modafinil co-treatment was significantly higher than after GBR12909 only $(\mathrm{F}(1,14)=4.9, \mathrm{P}=0.044)$ but not different from the SSV/saline control condition (Fig. 5).

\subsection{Fluoxetine and modafinil (Fig. 6, Supplementary Table 6)}

As in the previous experiments, startle amplitudes were higher in Balb/c mice than in C57B1/6 mice (main effect of Strain $\mathrm{F}(1,21)=27.2, \mathrm{P}<0.001)$. Fluoxetine treatment increased startle amplitudes (main effect $\mathrm{F}(1,21)=28.8, \mathrm{P}<0.001$ ) and this effect was more prominent in $\mathrm{Balb} / \mathrm{c}$ mice than in $\mathrm{C} 57 \mathrm{Bl} / 6$ mice (Flu x Strain interaction $\mathrm{F}(1,21)=8.0, \mathrm{P}=0.010$, Fig. 6). Further analysis by strain showed that the startle increase was significant in both C57Bl/6 $(\mathrm{F}(1,11)=6.6, \mathrm{P}=0.026)$ and $\mathrm{Balb} / \mathrm{c}$ mice $(\mathrm{F}(1,10)=20.9, \mathrm{P}=0.001)$ at the level of main effects (Fig. 6).

At the $30 \mathrm{~ms}$ ISI, PPI was again higher in Balb/c mice than in C57B1/6 mice (main effect of Strain $\mathrm{F}(1,22)=16.7, \mathrm{P}<0.001)$. Modafinil disrupted PPI (main effect $\mathrm{F}(1,22)=5.9, \mathrm{P}=0.024)$ and this effect was independent of fluoxetine co-treatment (Fig. 6). Analysis by strain showed that the effect of modafinil was significant in $\mathrm{C} 57 \mathrm{~B} 1 / 6$ mice $(\mathrm{F}(1,11)=6.3, \mathrm{P}=0.029)$ but not in Balb/c mice (Fig. 6). Further pair-wise comparison showed significant PPI disruption in $\mathrm{C} 57 \mathrm{Bl} / 6$ treated with either modafinil $(\mathrm{P}=0.042)$ or with fluoxetine and modafinil $(\mathrm{P}=0.033)$ compared to control.

At the $100 \mathrm{~ms}$ ISI, Balb/c mice had higher PPI than C57Bl/6 mice (main effect of Strain $\mathrm{F}(1,22)=47.6, \mathrm{P}<0.001$ ). Modafinil disrupted PPI (main effect $\mathrm{F}(1,22)=9.9, \mathrm{P}=0.005$ ) in $\mathrm{C} 57 \mathrm{Bl} / 6$ but not Balb/c mice (Mod x Strain interaction $\mathrm{F}(1,22)=9.1, \mathrm{P}=0.006)$. Further 
analysis by strain confirmed an effect of modafinil in C57Bl/6 mice only (main effect $\mathrm{F}(1,11)=17.0, \mathrm{P}=0.002)$. Pair-wise comparison showed that this was significant for both modafinil on its own $(\mathrm{P}=0.012)$ or in combination with fluoxetine $(\mathrm{P}=0.031)$. Conversely, there were no effects of fluoxetine on its own or vs. the action of modafinil (Fig. 6).

\section{DISCUSSION}

The most important results in this study were that (1) oral treatment with $100 \mathrm{mg} / \mathrm{kg}$, but not lower doses, of modafinil produced significant reduction of PPI in C57Bl/6 mice but not in Balb/c mice; (2) co-treatment with haloperidol or ketanserin blocked the effect of modafinil on PPI; (3) a dose of modafinil which did not affect PPI blocked the PPI disruption by GBR12909; (4) in contrast, co-treatment with either WAY100,635 or fluoxetine had no effect on the action of modafinil on PPI.

In previous in vivo studies, haloperidol bound to dopamine $\mathrm{D}_{2}$ receptors but low doses had little effect on $5-\mathrm{HT}_{2 \mathrm{~A}}$, histamine $\mathrm{H}_{1}$ or muscarinic $\mathrm{M}_{1}$ receptors (Schotte et al., 1994). Thus, an involvement of dopamine $\mathrm{D}_{2}$ receptors in the action of haloperidol to antagonize the effect of modafinil on PPI is likely. This would be consistent with other studies suggesting a role of these receptors in the effects of modafinil, including in mice. For example, the wakefulnesspromoting and arousal effects of modafinil were blocked by treatment with the dopamine $\mathrm{D}_{2}$ receptor antagonist, raclopride, and were absent in dopamine $\mathrm{D}_{2}$ receptor knockout mice $(\mathrm{Qu}$ et al., 2008). In vitro experiments showed that modafinil inhibited the firing of dopaminergic neurons in the midbrain and that this effect could be blocked by the dopamine $\mathrm{D}_{2}$ receptor antagonist, sulpiride (Korotkova et al., 2007). In contrast, haloperidol pre-treatment was unable to block the locomotor hyperactivity induced by modafinil in mice although it was 
effective against the action of amphetamine in these animals (Simon et al., 1995). Further experiments should address the possible involvement of dopamine $\mathrm{D}_{1}$ receptors in the action of modafinil on PPI, which remains unclear (Qu et al., 2008; Young and Geyer, 2010). An interaction of modafinil at the dopamine transporter was suggested in studies combining the effect of GBR12909 and $30 \mathrm{mg} / \mathrm{kg}$ of modafinil. In this experiment, modafinil, at a dose which did not significantly affect PPI, significantly inhibited the disruption of PPI seen after treatment with GBR12909. These results suggest that GBR12909 and modafinil may have the same pharmacological site of action, i.e. both need to bind to the dopamine transporter to elicit the reduction of PPI. Such an interpretation would be in line with binding studies (Zolkowska et al., 2009) and clinical imaging studies (Volkow et al., 2009) which have provided evidence that modafinil may bind to the dopamine transporter both in vitro and in vivo. In addition, our results on the interaction of modafinil and GBR12909 on PPI are reminiscent of previous studies where modafinil, when administered before methamphetamine, inhibited its effect in rats on dopamine transporter function, locomotion and dopamine release in the nucleus accumbens (Zolkowska et al., 2009). In mice, modafinil treatment has recently been shown to attenuate methamphetamine toxicity (Raineri et al., 2011).

In an attempt to investigate the involvement of serotonergic mechanisms in the action of modafinil on PPI, we administered it in combination with ketanserin, WAY100,635 or fluoxetine. Ketanserin, but not WAY100,635 co-treatment blocked the PPI disruption induced by modafinil, suggesting an involvement of 5- $\mathrm{HT}_{2 \mathrm{~A}}$ receptors, but not $5-\mathrm{HT}_{1 \mathrm{~A}}$ receptors. An action of modafinil on PPI via 5- $\mathrm{HT}_{2 \mathrm{~A}}$ receptors resembles the effects of 5- $\mathrm{HT}_{2 \mathrm{~A}}$ receptor agonists, such as 1-(2,5-dimethoxy-4-iodophenyl)-aminopropane (DOI) and psilocybin, which also cause PPI disruption (Geyer et al., 2001). Microdialysis studies have confirmed that 
modafinil administration stimulates serotonin release in the frontal cortex and dorsal raphe nucleus (de Saint Hilaire et al., 2001; Ferraro et al., 2005). However, it is less clear whether modafinil exerts this effect by binding to the serotonin transporter. Binding studies did not reveal any appreciable affinity of modafinil for serotonin transporters (Zolkowska et al., 2009). In addition, in our experiments, co-treatment of the mice with fluoxetine had no effect on the action of modafinil on PPI. Previous studies suggesting modafinil could modulate the action of antidepressant drugs (Ferraro et al., 2005; Minzenberg and Carter, 2008) therefore likely represent an indirect interaction rather than a direct one.

While the blocking effects of haloperidol and ketanserin suggest involvement of both dopamine $\mathrm{D}_{2}$ receptors and $5-\mathrm{HT}_{2 \mathrm{~A}}$ receptors in the action of modafinil, it is not clear how these two receptor systems interact with each other. If modafinil was merely stimulating dopamine release via an effect on the dopamine transporter and at the same time independently stimulating serotonin release via another action, then neither haloperidol nor ketanserin would be expected to completely block the action of modafinil on PPI. There are a number of possibilities which could explain this finding. Dopaminergic and serotonergic effects of modafinil may occur 'in series' i.e. modafinil first interacts with the dopamine transporter to release dopamine which stimulates dopamine $\mathrm{D}_{2}$ receptors, an effect which can be blocked by haloperidol co-treatment. The second step could be that this dopaminergic activation elicits a serotonergic activation which ultimately leads to 5- $\mathrm{HT}_{2 \mathrm{~A}}$ receptor stimulation and a decrease of PPI. A reciprocal interaction has been suggested between ventral tegmental area dopamine neurons and serotonin neurons in the dorsal raphe nucleus. For example, dopamine receptor agonists have been shown to modulate extracellular serotonin levels in the dorsal raphe nucleus which may indirectly alter serotonin cell excitability and the activity of ascending forebrain serotonin neurons (Ferré and Artigas, 
1993; Aman et al., 2007). Such a sequence of events could explain why both haloperidol and ketanserin are able to completely block the effect of modafinil on PPI and could also explain why the effect of modafinil does not need to be via a direct interaction with the serotonin transporter. Alternatively, the effect of modafinil via dopamine $\mathrm{D}_{2}$ receptors or via $5-\mathrm{HT}_{2 \mathrm{~A}}$ receptors is sub-threshold and only if both mechanisms are activated does the summation of these sub-threshold effects lead to PPI disruption. In this scenario, blocking either dopamine $\mathrm{D}_{2}$ receptors with haloperidol or $5-\mathrm{HT}_{2 \mathrm{~A}}$ receptors with ketanserin will reduce the effect of modafinil to an ineffective level. Whichever of these mechanisms is involved in the present results, it is tempting to compare these dopamine/serotonin interactions with the proposed involvement of both neurotransmitter systems in schizophrenia and the action of some atypical antipsychotics which display affinity for both dopamine $\mathrm{D}_{2}$ receptors and $5-\mathrm{HT}_{2 \mathrm{~A}}$ receptors.

We used both C57B1/6 mice and Balb/c mice to study the effects of modafinil on PPI. As outlined above and confirmed in the present results, these strains showed markedly different levels of PPI and its pharmacological regulation (Paylor and Crawley, 1997; Van den Buuse et al., 2007). Balb/c mice tend to have higher startle responses and PPI, are more responsive to treatment with the serotonin-1A receptor agonist, 8-OH-DPAT, but are less responsive to amphetamine than compared to C57Bl/6 mice (Van den Buuse et al., 2007). At the doses we tested, modafinil had no effect on PPI or startle in Balb/c mice, similar to our previously published findings of the lack of effect of amphetamine on PPI in this strain (Van den Buuse et al., 2007). On the other hand, Balb/c mice display significantly higher levels of tyrosine hydroxylase in the midbrain and a $31 \%$ increase in the number of tyrosine hydroxylasepositive neurons in the substantia nigra (Vadasz et al., 2007) although these increases are obviously not sufficient to compensate for the reduced dopamine transporter density in this 
strain. Despite their greater sensitivity to effects of serotonergic stimulation on PPI, Balb/c mice also did not reveal any PPI changes after combined treatment of modafinil and ketanserin or WAY100,635. The observed strain differences in our study suggest a marked genetic influence on the extent and mechanism of the effect of modafinil on PPI. It should be noted that such genetic effects, in addition to differential responsiveness of dopaminergic and serotonergic systems in the brain, could also be at the level of absorption and distribution of modafinil. Further pharmacodynamic and pharmacokinetic studies in $\mathrm{C} 57 \mathrm{Bl} / 6$ and $\mathrm{Balb} / \mathrm{c}$ mice are needed to exclude this possible mechanism to explain the strain differences.

Limitations of this study are, that only single doses were tested and not the steady-state levels which would be obtained after chronic administration. It can also not be excluded that the effects of the antagonists vs. modafinil were influenced by drug-drug interactions modulating the absorption rate of the orally administered drug. Further experiments using intravenous or intracerebroventricular treatment with modafinil are required to circumvent this possibility.

In conclusion, oral treatment with modafinil caused a significant disruption of PPI in C57Bl/6 mice, but not Balb/c mice. The effect of modafinil most likely involved an interaction with the dopamine transporter ultimately leading to stimulation of dopamine $\mathrm{D}_{2}$ receptors and $5-\mathrm{HT}_{2 \mathrm{~A}}$ receptors. These results extend our insight into the effects of modafinil on behavior and show that, at higher doses, one of the detrimental effects of this wakefulness-promoting agent could be PPI disruption mediated by either dopaminergic and serotonergic activation or both. This effect was only seen in $\mathrm{C} 57 \mathrm{Bl} / 6$ mice which indicates these risks are stongly dependent on the genetic background. These results could be of importance for the clinical use of modafinil as they suggest a risk of effects on sensorimotor gating which could be especially detrimental against a specific genetic background and in conditions where this is already reduced, such as 
in schizophrenia and bipolar disorder (Morein-Zamir et al., 2007; Saavedra-Velez et al., 2009; Young and Geyer, 2010). Further studies are therefore needed in animal models of schizophrenia with reduced PPI (van den Buuse, 2010) to assess risks of modafinil treatment in such conditions. Furthermore, it will be important to assess whether the effect of modafinil extends to other forms of sensory gating which are also disrupted in schizophrenia.

\section{ACKNOWLEDGEMENTS}

The authors acknowledge the technical assistance of Jack Kee Low and Sally Martin with parts of the experiments. M. van den Buuse is a Senior Research Fellow of the National Health and Medical Research Council of Australia (NHMRC). P. Kwek was supported by a project grant from the NHMRC. These studies were furthermore supported by the Percy Baxter Charitable Trust, Australia, and Operational Infrastructure Funding from the State Government of Victoria, Australia. None of these funding sources had any influence in study design, the collection, analysis and interpretation of data, the writing of the manuscript or in the decision to submit it for publication. There are no conflicts of interest to disclose.

\section{REFERENCES}

Aman, T.K., Shen, R.Y.Haj-Dahmane, S., 2007. D 2 -like dopamine receptors depolarize dorsal raphe serotonin neurons through the activation of nonselective cationic conductance. J. Pharmacol. Exp. Ther. 320, 376-385.

Assié, M.B., Dominguez, H., Consul-Denjean, N.Newman-Tancredi, A., 2006. In vivo occupancy of dopamine $\mathrm{D}_{2}$ receptors by antipsychotic drugs and novel compounds in the mouse striatum and olfactory tubercles. Naunyn-Schmied. Arch. Pharmacol. 373, 441-450. 
Bertrand, P.P., Paranavitane, U.T., Chavez, C., Gogos, A., Jones, M.van den Buuse, M., 2005. The effect of low estrogen state on serotonin transporter function in mouse hippocampus: A behavioral and electrochemical study. Brain Res. 1064, 10-20.

Bradford, A.M., Savage, K.M., Jones, D.N.Kalinichev, M., 2010. Validation and pharmacological characterisation of MK-801-induced locomotor hyperactivity in BALB/c mice as an assay for detection of novel antipsychotics. Psychopharmacology $212,155-170$.

de Saint Hilaire, Z., Orosco, M., Rouch, C., Blanc, G.Nicolaidis, S., 2001. Variations in extracellular monoamines in the prefrontal cortex and medial hypothalamus after modafinil administration: a microdialysis study in rats. Neuroreport 12, 3533-3537.

Ferraro, L., Fuxe, K., Agnati, L., Tanganelli, S., Tomasini, M.C.Antonelli, T., 2005. Modafinil enhances the increase of extracellular serotonin levels induced by the antidepressant drugs fluoxetine and imipramine: a dual probe microdialysis study in awake rat. Synapse 55, 230-241.

Ferré, S.Artigas, F., 1993. Dopamine $\mathrm{D}_{2}$ receptor-mediated regulation of serotonin extracellular concentration in the dorsal raphe nucleus of freely moving rats. J. Neurochem. 61, 772-775. 
Geyer, M.A., Krebs-Thomson, K., Braff, D.L.Swerdlow, N.R., 2001. Pharmacological studies of prepulse inhibition models of sensorimotor gating deficits in schizophrenia: a decade in review. Psychopharmacology 156, 117-154.

Gleason, S.D.Shannon, H.E., 1997. Blockade of phencyclidine-induced hyperlocomotion by olanzapine, clozapine and serotonin receptor subtype selective antagonists in mice. Psychopharmacology 129, 79-84.

Heinzerling, K.G., Swanson, A.N., Kim, S., Cederblom, L., Moe, A., Ling, W.Shoptaw, S., 2010. Randomized, double-blind, placebo-controlled trial of modafinil for the treatment of methamphetamine dependence. Drug Alcohol. Depend. 109, 20-29.

Ishizuka, T., Murakami, M.Yamatodani, A., 2008. Involvement of central histaminergic systems in modafinil-induced but not methylphenidate-induced increases in locomotor activity in rats. Euro. J. Pharmacol. 578, 209-215.

Korotkova, T.M., Klyuch, B.P., Ponomarenko, A.A., Lin, J.S., Haas, H.L.Sergeeva, O.A., 2007. Modafinil inhibits rat midbrain dopaminergic neurons through $\mathrm{D}_{2}$-like receptors. Neuropharmacology 52, 626-633.

Krebs-Thomson, K., Ruiz, E.M., Masten, V., Buell, M.Geyer, M.A., 2006. The roles of 5$\mathrm{HT}_{1 \mathrm{~A}}$ and $5-\mathrm{HT}_{2}$ receptors in the effects of 5-MeO-DMT on locomotor activity and prepulse inhibition in rats. Psychopharmacology 189, 319-329. 
Kumar, R., 2008. Approved and investigational uses of modafinil : an evidence-based review. Drugs 68, 1803-1839.

Liu, Y.P., Tung, C.S., Chuang, C.H., Lo, S.M.Ku, Y.C., 2011. Tail-pinch stress and REM sleep deprivation differentially affect sensorimotor gating function in modafiniltreated rats. Behav. Brain Res. 219, 98-104.

Ma, Z.Q., Hong, Z.Y., Wang, W.S.Tao, F., 2012. [Pharmacokinetics--pharmacodynamics of modafinil in mice]. Yao Xue Xue Bao 47, 101-104.

Martinez-Raga, J., Knecht, C.Cepeda, S., 2008. Modafinil: a useful medication for cocaine addiction? Review of the evidence from neuropharmacological, experimental and clinical studies. Curr. Drug Abuse Rev. 1, 213-221.

McCaughran, J., Mahjubi, E., Decena, E.Hitzemann, R., 1997. Genetics, haloperidol-induced catalepsy and haloperidol-induced changes in acoustic startle and prepulse inhibition. Psychopharmacology 134, 131-139.

McFadden, S.L., Zulas, A.L.Morgan, R.E., 2010. Age-dependent effects of modafinil on acoustic startle and prepulse inhibition in rats. Behav. Brain Res. 208, 118-123.

Mcgeehan, A.J., Janak, P.H.Olive, M.F., 2004. Effect of the mGluR5 antagonist 6-methyl-2(phenylethynyl)pyridine (MPEP) on the acute locomotor stimulant properties of cocaine, D-amphetamine, and the dopamine reuptake inhibitor GBR12909 in mice. Psychopharmacology 174, 266-273. 
Minzenberg, M.J.Carter, C.S., 2008. Modafinil: A review of neurochemical actions and effects on cognition. Neuropsychopharmacology 33, 1477-1502.

Morein-Zamir, S., Turner, D.C.Sahakian, B.J., 2007. A review of the effects of modafinil on cognition in schizophrenia. Schizophr. Bull. 33, 1298-1306.

Paylor, R.Crawley, J.N., 1997. Inbred strain differences in prepulse inhibition of the mouse startle response. Psychopharmacology 132, 169-180.

Qu, W.M., Huang, Z.L., Xu, X.H., Matsumoto, N.Urade, Y., 2008. Dopaminergic $\mathrm{D}_{1}$ and $\mathrm{D}_{2}$ receptors are essential for the arousal effect of modafinil. J. Neurosci. 28, 8462-8469.

Raineri, M., Peskin, V., Goitia, B., Taravini, I.R.E., Giorgeri, S., Urbano, F.J.Bisagno, V., 2011. Attenuated methamphetamine induced neurotoxicity by modafinil administration in mice. Synapse 65, 1087-1098.

Rao, R.N.Shinde, D.D., 2009. Enantioselective separation and determination of adrafinil and modafinil on Chiralcel OJ-H column in rat serum and urine using solid-phase extraction followed by HPLC. Med. Chromatogr. 23, 811-816.

Regenthal, R., Koch, H., Kohler, C., Preiss, R.Krugel, U., 2009. Depression-like deficits in rats improved by subchronic modafinil. Psychopharmacology 204, 627-639. 
Saavedra-Velez, C., Yusim, A., Anbarasan, D.Lindenmayer, J.P., 2009. Modafinil as an adjunctive treatment of sedation, negative symptoms, and cognition in schizophrenia: a critical review. J. Clin. Psychiatry 70, 104-112.

Samuels, E.R., Hou, R.H., Langley, R.W., Szabadi, E.Bradshaw, C.M., 2007. Modulation of the acoustic startle response by the level of arousal: Comparison of clonidine and modafinil in healthy volunteers. Neuropsychopharmacology 32, 2405-2421.

Schotte, A., Janssen, P.F.M., Megens, A.A.H.P.Leysen, J.E., 1994. Occupancy of central neurotransmitter receptors by risperidone, clozapine and haloperidol, measured ex vivo by quantitative autoradiography. Brain Res. 631, 191-202.

Simon, P., Hemet, C.Costentin, J., 1996. Analysis of stimulant locomotor effects of modafinil in various strains of mice and rats. Fundam. Clin. Pharmacol. 10, 431-435.

Simon, P., Hémet, C., Ramassamy, C.Costentin, J., 1995. Non-amphetaminic mechanism of stimulant locomotor effect of modafinil in mice. Eur. Neuropsychopharmacol. 5, 509514.

Swerdlow, N.R., Talledo, J., Sutherland, A.N., Nagy, D.Shoemaker, J.M., 2006.

Antipsychotic effects on prepulse inhibition in normal 'low gating' humans and rats. Neuropsychopharmacology 31, 2011-2021. 
Swerdlow, N.R., Weber, M., Qu, Y., Light, G.A.Braff, D.L., 2008. Realistic expectations of prepulse inhibition in translational models for schizophrenia research. Psychopharmacology 199, 331-338.

Trillat, A.C., Malagié, I., Mathé-Allainmat, M., Anmela, M.C., Jacquot, C., Langlois, M.Gardier, A.M., 1998. Effects of WAY 100635 and (-)-5-Me-8-OH-DPAT, a novel 5-HT $\mathrm{HA}_{1 \mathrm{~A}}$ receptor antagonist, on 8-OH-DPAT responses. Euro. J. Pharmacol. 347, 4149.

Vadasz, C., Smiley, J.F., Figarsky, K., Saito, M., Toth, R., Gyetvai, B.M., Oros, M., Kovacs, K.K., Mohan, P.Wang, R., 2007. Mesencephalic dopamine neuron number and tyrosine hydroxylase content: Genetic control and candidate genes. Neuroscience 149, 561-572.

van den Buuse, M., 2010. Modeling the positive symptoms of schizophrenia in genetically modified mice: Pharmacology and methodology aspects. Schizophr. Bull. 36, 246270.

Van den Buuse, M., Martin, S., Holgate, J., Matthaei, K.Hendry, I., 2007. Mice deficient in the alpha subunit of $\mathrm{G}_{\mathrm{z}}$ show changes in pre-pulse inhibition, anxiety and responses to $5-\mathrm{HT}_{1 \mathrm{~A}}$ receptor stimulation, which are strongly dependent on the genetic background. Psychopharmacology 195, 273-283.

Volkow, N.D., Fowler, J.S., Logan, J., Alexoff, D., Zhu, W., Telang, F., Wang, G.J., Jayne, M., Hooker, J.M., Wong, C., Hubbard, B., Carter, P., Warner, D., King, P., Shea, C., 
Xu, Y., Muench, L.Apelskog-Torres, K., 2009. Effects of modafinil on dopamine and dopamine transporters in the male human brain: clinical implications. JAMA 201, 1148-1154.

Vollenweider, F.X., Csomor, P.A., Knappe, B., Geyer, M.A.Quednow, B.B., 2007. The effects of the preferential 5- $\mathrm{HT}_{2 \mathrm{~A}}$ agonist psilocybin on prepulse inhibition of startle in healthy human volunteers depend on interstimulus interval. Neuropsychopharmacology 32, 1876-1887.

Young, J.W.Geyer, M.A., 2010. Action of modafinil--increased motivation via the dopamine transporter inhibition and $\mathrm{D}_{1}$ receptors? Biol. Psychiatry 67, 784-787.

Young, J.W., Goey, A.K.L., Minassian, A., Perry, W., Paulus, M.P.Geyer, M.A., 2010. GBR 12909 administration as a mouse model of bipolar disorder mania: mimicking quantitative assessment of manic behavior. Psychopharmacology 208, 443-454.

Zolkowska, D., Jain, R., Rothman, R.B., Partilla, J.S., Roth, B.L., Setola, V., Prisinzano, T.E.Baumann, M.H., 2009. Evidence for the involvement of dopamine transporters in behavioral stimulant effects of modafinil. J. Pharmacol. Exp. Ther. 329, 738-746.

\section{LEGENDS TO FIGURES}

Fig. 1

The effect of modafinil on startle amplitude (top panel), PPI at the $30 \mathrm{~ms}$ ISI (middle panel) and PPI at the $100 \mathrm{~ms}$ ISI (bottom panel) in C57B1/6 mice and Balb/c mice. Modafinil was 
orally administered at 0 (Vehicle only, Veh), 3, 10, 30 or $100 \mathrm{mg} / \mathrm{kg}$. At the highest dose, modafinil significantly reduced PPI. This effect was seen in C57B1/6 mice, but not Balb/c mice. ${ }^{*} \mathrm{P}<0.05$ for difference with vehicle treatment.

Fig. 2

The effect of $100 \mathrm{mg} / \mathrm{kg}$ of modafinil and $0.3 \mathrm{mg} / \mathrm{kg}$ of haloperidol on startle amplitude (top panel), PPI at the $30 \mathrm{~ms}$ ISI (middle panel) and PPI at the $100 \mathrm{~ms}$ ISI (bottom panel) in C57B1/6 mice and Balb/c mice. In C57Bl/6 mice, but not Balb/c mice, modafinil significantly reduced PPI at the $100 \mathrm{~ms}$ ISI. This effect was not seen after co-treatment with haloperidol, which had no effect on PPI on its own. $* \mathrm{P}<0.05$ for difference with vehicle (Veh) treatment. \# $\mathrm{P}<0.05$ for difference with modafinil (Mod) treatment.

Fig. 3

The effect of $100 \mathrm{mg} / \mathrm{kg}$ of modafinil and $1 \mathrm{mg} / \mathrm{kg}$ of ketanserin on startle amplitude (top panel), PPI at the $30 \mathrm{~ms}$ ISI (middle panel) and PPI at the $100 \mathrm{~ms}$ ISI (bottom panel) in $\mathrm{C} 57 \mathrm{Bl} / 6$ mice and Balb/c mice. In C57Bl/6 mice, but not Balb/c mice, modafinil significantly reduced PPI. This effect was not seen after co-treatment with ketanserin, which had no effect on PPI on its own. * $\mathrm{P}<0.05$ for difference with vehicle (Veh) treatment. \# $\mathrm{P}<0.05$ for difference with modafinil (Mod) treatment.

Fig. 4

The effect of $100 \mathrm{mg} / \mathrm{kg}$ of modafinil and $1 \mathrm{mg} / \mathrm{kg}$ of WAY100,635 on startle amplitude (top panel), PPI at the $30 \mathrm{~ms}$ ISI (middle panel) and PPI at the $100 \mathrm{~ms}$ ISI (bottom panel) in $\mathrm{C} 57 \mathrm{Bl} / 6$ mice and Balb/c mice. In C57Bl/6 mice, but not Balb/c mice, modafinil significantly reduced PPI. This effect was not significantly affected by co-treatment with WAY100,635, 
which also had no effect on PPI on its own. ${ }^{*} \mathrm{P}<0.05$ for difference with vehicle (Veh) treatment.

Fig. 5

The effect of $30 \mathrm{mg} / \mathrm{kg}$ of modafinil and $5 \mathrm{mg} / \mathrm{kg}$ of GBR12909 on startle amplitude (top panel), PPI at the $30 \mathrm{~ms}$ ISI (middle panel) and PPI at the $100 \mathrm{~ms}$ ISI (bottom panel) in C57B1/6 mice. GBR12909 significantly reduced PPI and this effect was blocked by cotreatment with modafinil, which did not affect PPI. ${ }^{*} \mathrm{P}<0.05$ for difference with vehicle (Veh) treatment. \# $\mathrm{P}<0.05$ for difference with GBR12909 treatment.

Fig. 6

The effect of $100 \mathrm{mg} / \mathrm{kg}$ of modafinil and $10 \mathrm{mg} / \mathrm{kg}$ of fluoxetine on startle amplitude (top panel), PPI at the $30 \mathrm{~ms}$ ISI (middle panel) and PPI at the $100 \mathrm{~ms}$ ISI (bottom panel) in $\mathrm{C} 57 \mathrm{Bl} / 6$ mice and Balb/c mice. In C57Bl/6 mice, but not Balb/c mice, modafinil significantly reduced PPI. This effect was not significantly affected by co-treatment with fluoxetine, which also had no effect on PPI on its own. * $\mathrm{P}<0.05$ for difference with vehicle (Veh) treatment. 
Startle

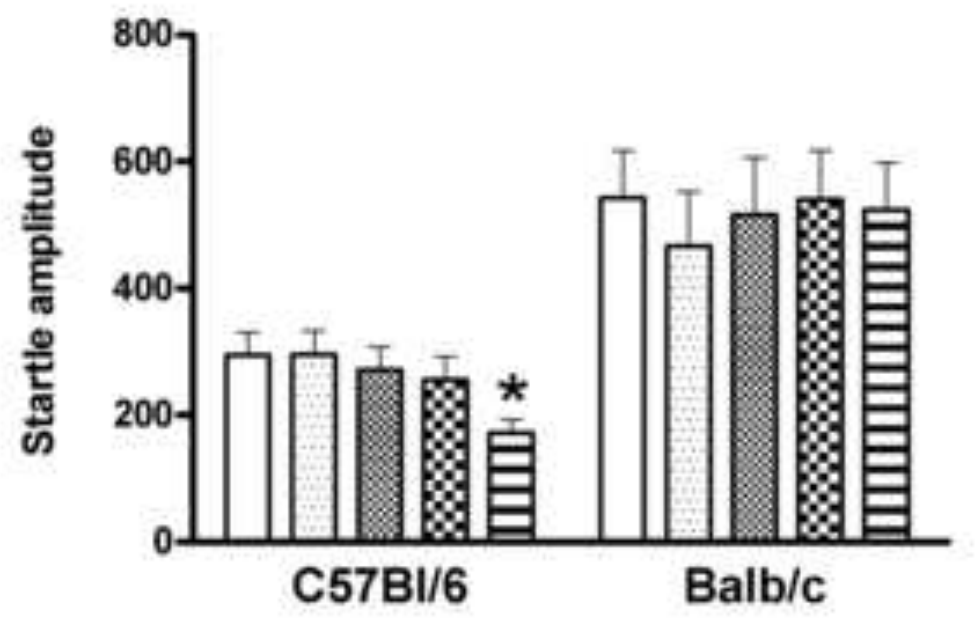

$30 \mathrm{~ms}$ ISI
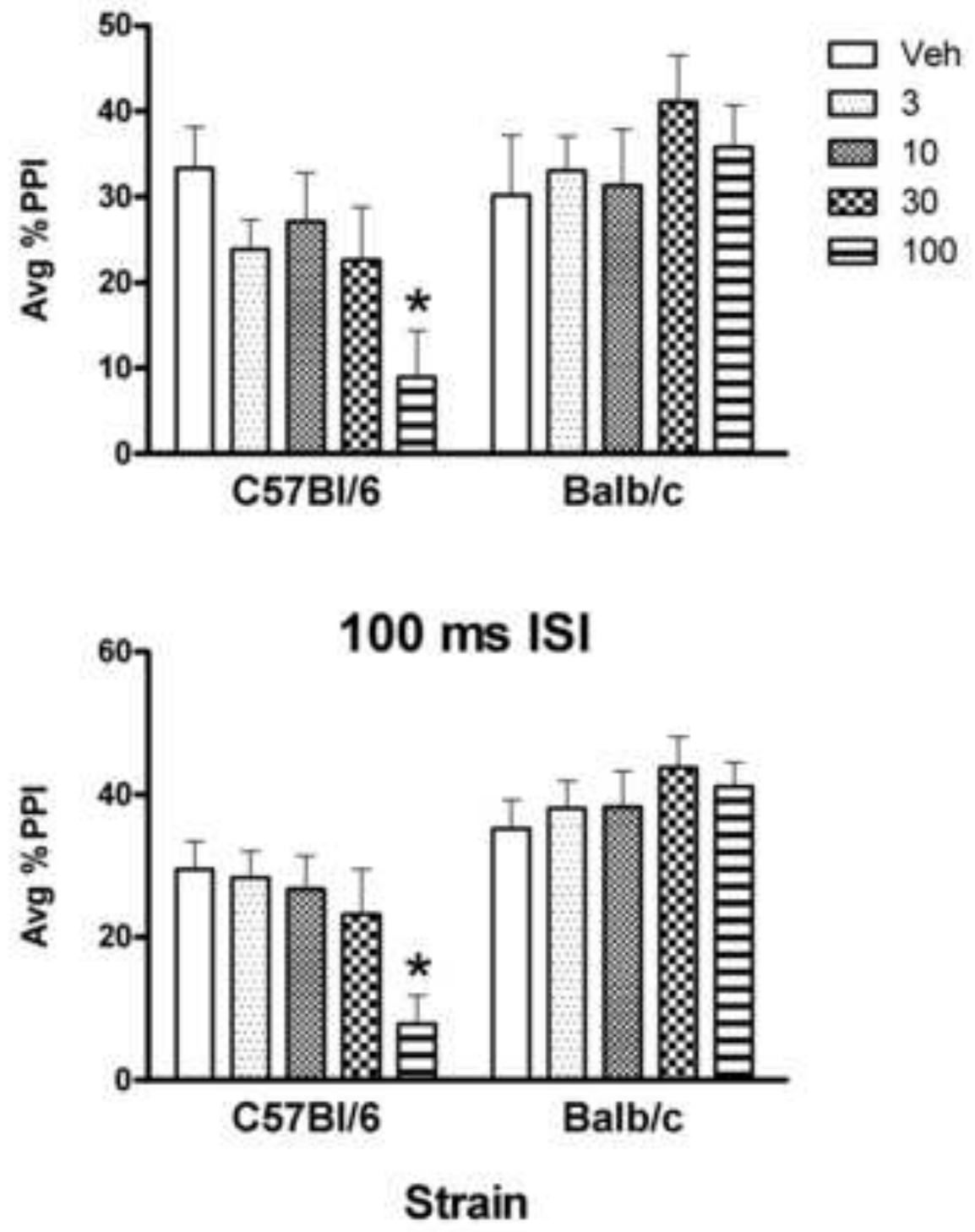

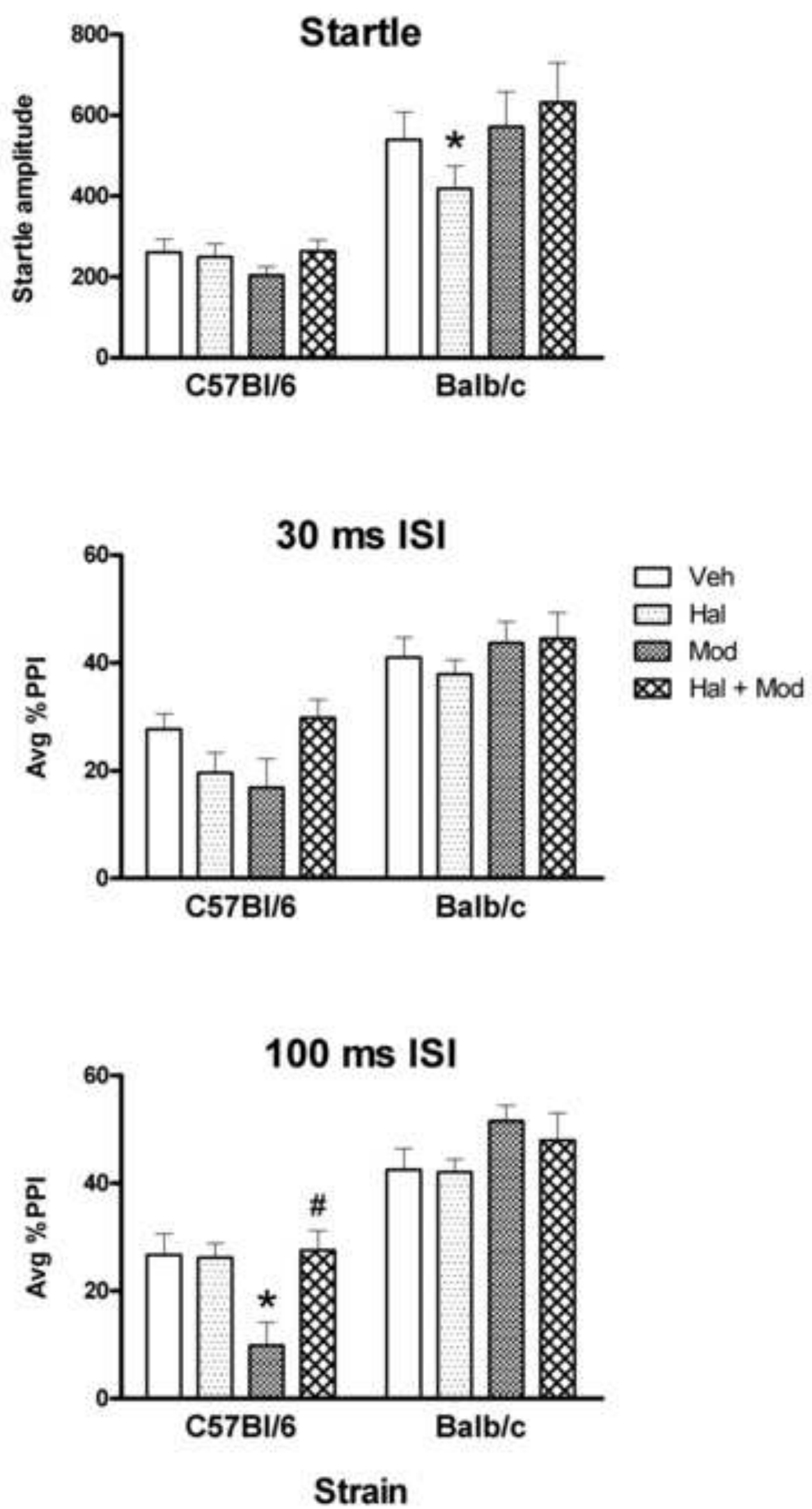

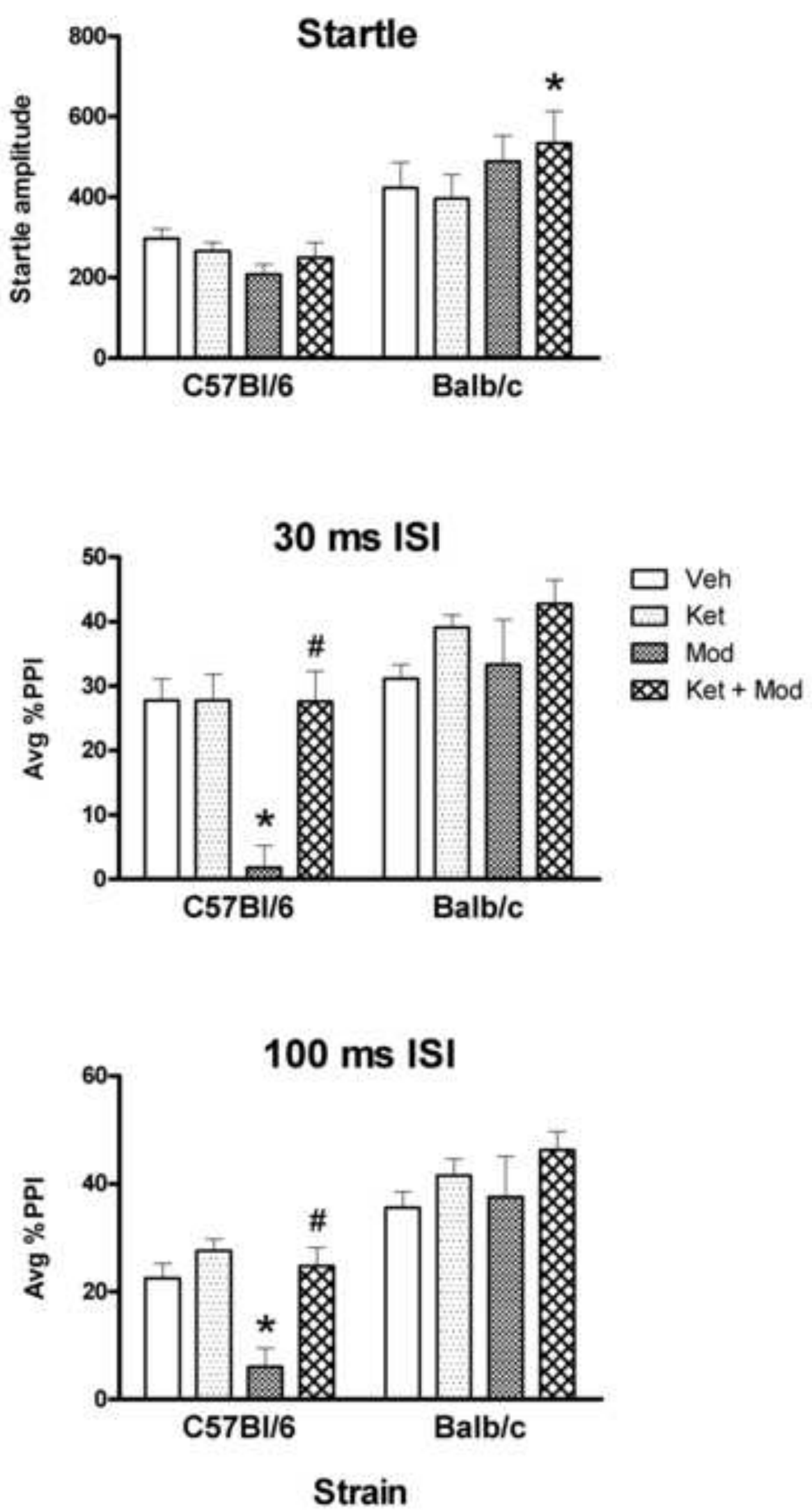

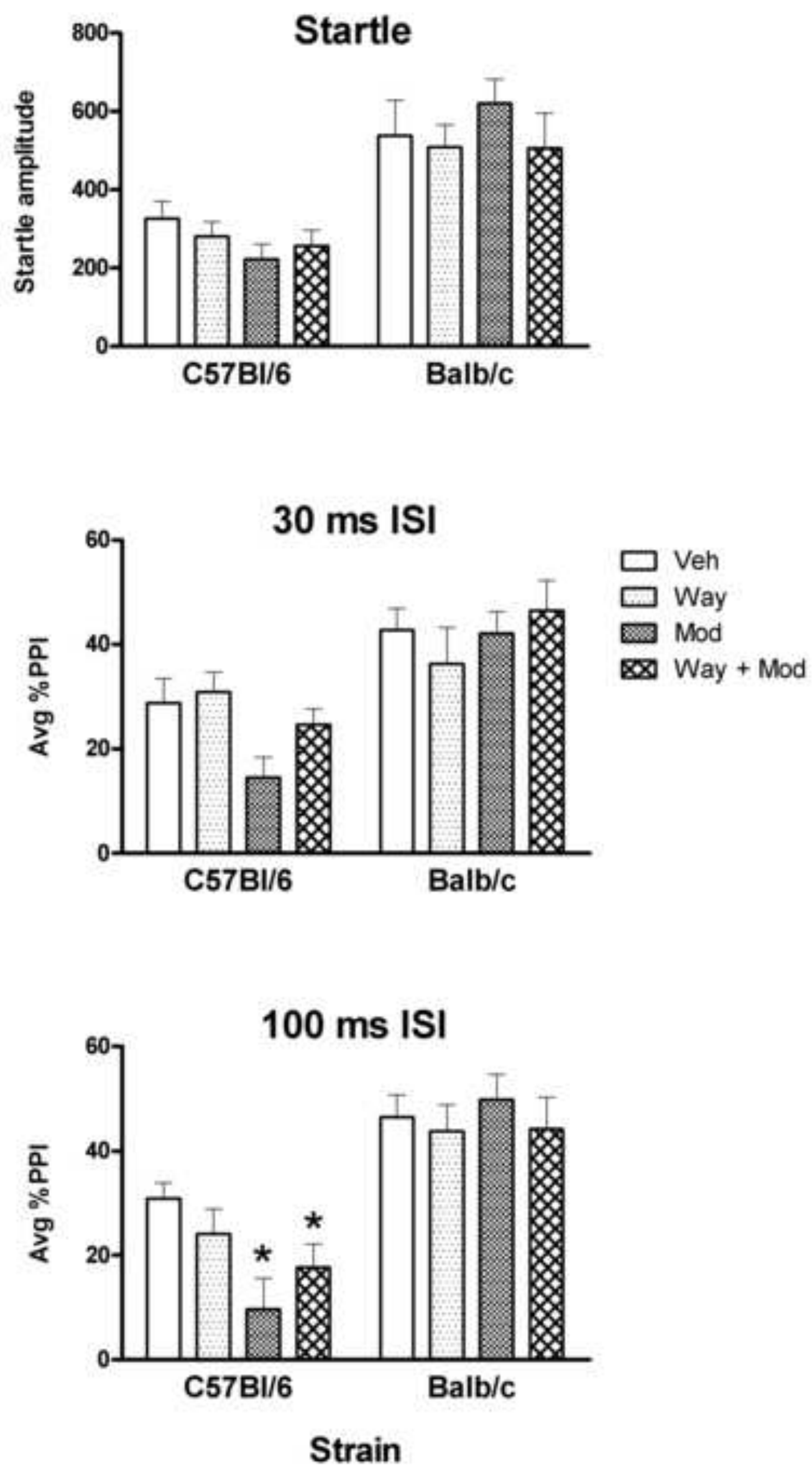

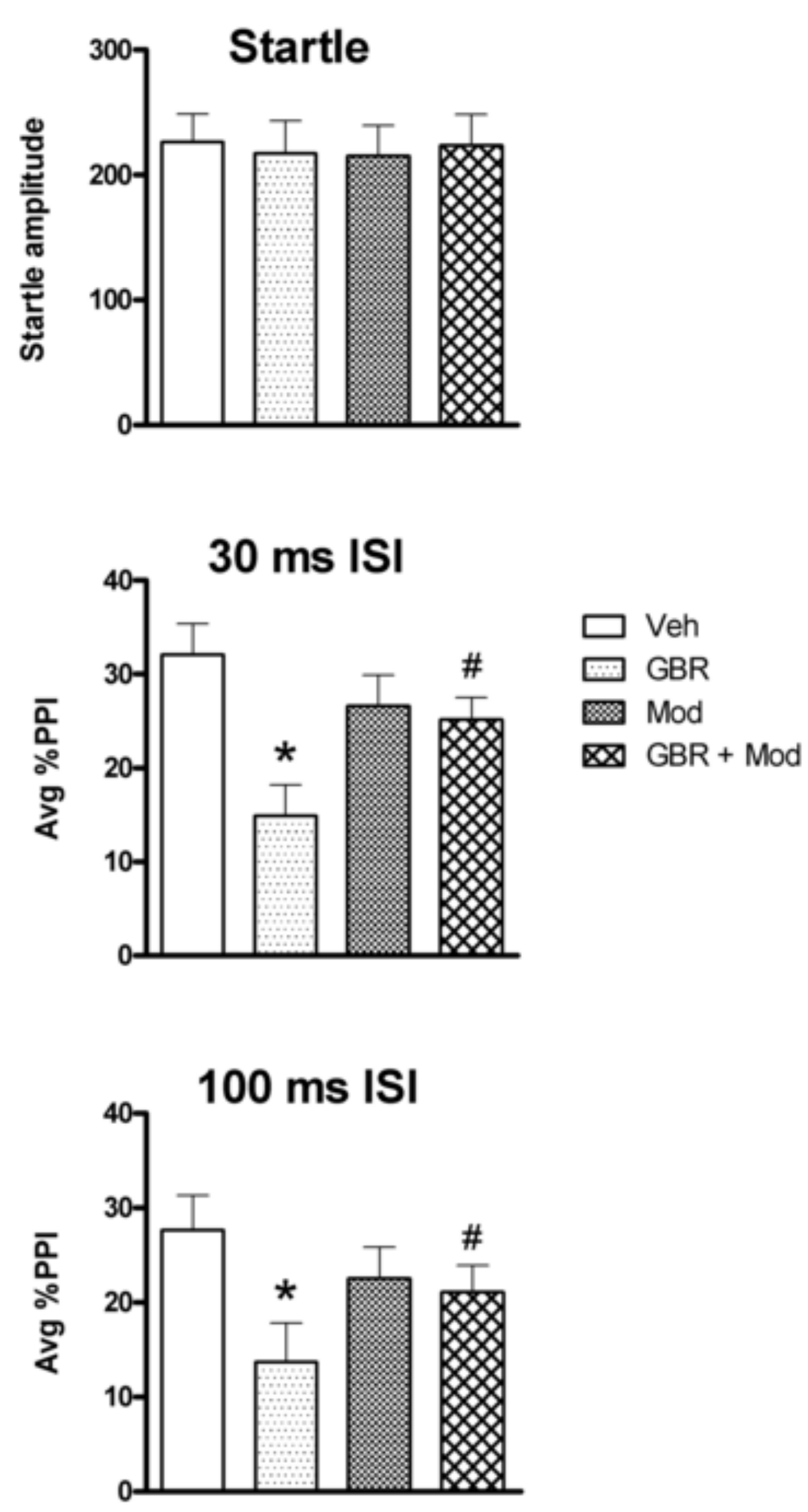

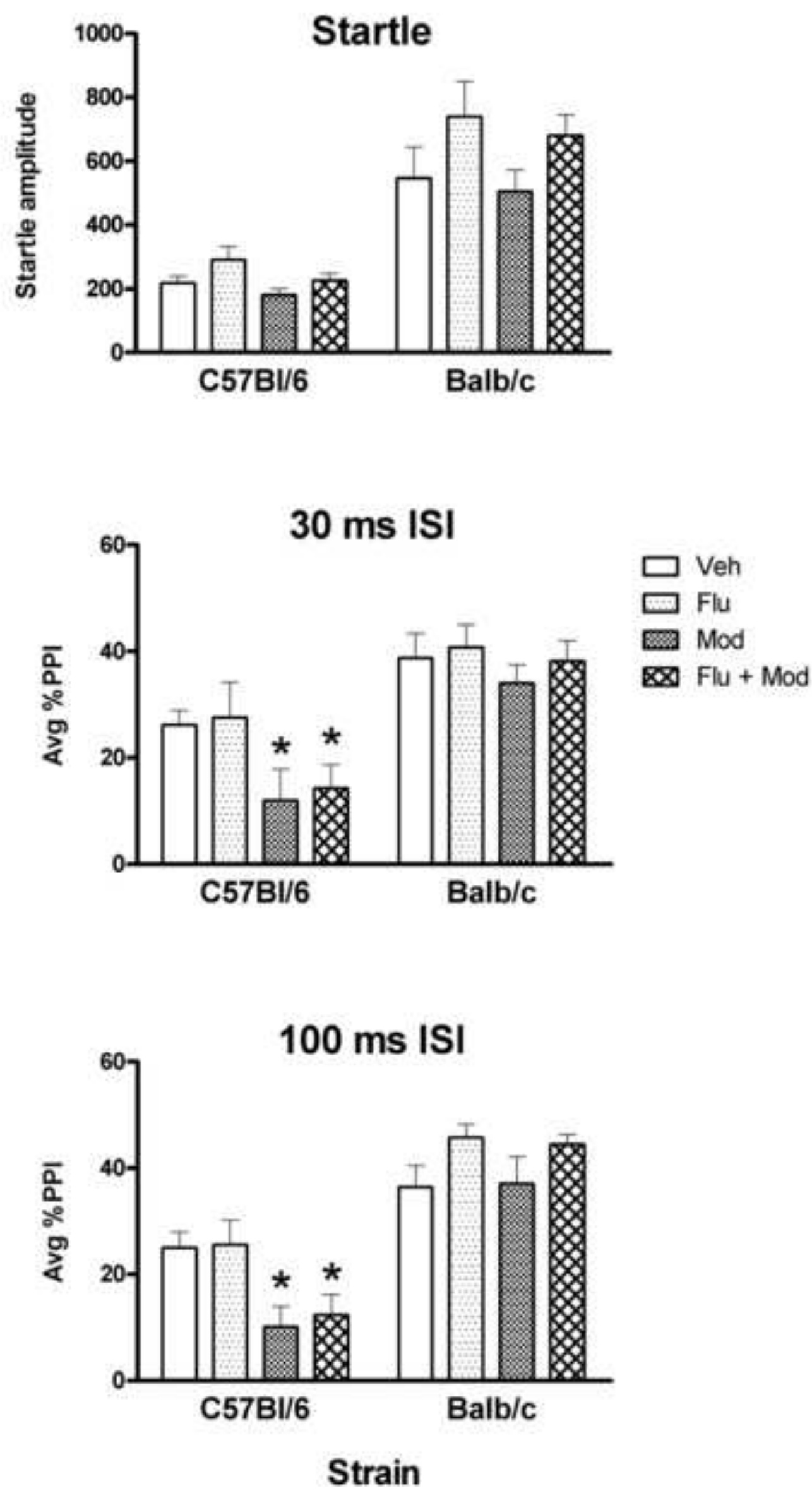


\section{University Library}

\section{- M M I N E R VA \\ A gateway to Melbourne's research publications}

Minerva Access is the Institutional Repository of The University of Melbourne

Author/s:

Kwek, P;van den Buuse, M

Title:

Modafinil disrupts prepulse inhibition in mice: Strain differences and involvement of dopaminergic and serotonergic activation

Date:

2013-01-15

\section{Citation:}

Kwek, P. \& van den Buuse, M. (2013). Modafinil disrupts prepulse inhibition in mice: Strain differences and involvement of dopaminergic and serotonergic activation. EUROPEAN JOURNAL OF PHARMACOLOGY, 699 (1-3), pp.132-140. https://doi.org/10.1016/ j.ejphar.2012.11.041.

Publication Status:

Accepted manuscript

Persistent Link:

http://hdl.handle.net/11343/41895 